\title{
Uric acid and cardiometabolic diseases
}

\author{
Seung Jae Lee ${ }^{\dagger}$, Byeong Kil $\mathrm{Oh}^{\dagger}$ and Ki-Chul Sung*
}

\begin{abstract}
Hyperuricemia, which has been considered as a cause of gout and nephrolithiasis has recently been suggested to be associated with hypertension, coronary heart disease, heart failure, atrial fibrillation, insulin resistance, and nonalcoholic fatty liver disease. Several clinical and experimental studies have supported uric acid (UA) as an independent risk factor for predicting disease development along with the traditional risk factors. The mechanism by which UA causes cardiometabolic disease has not been fully elucidated to date; however, it has been explained by several hypotheses such as oxidative stress, reduced nitric oxide bioavailability, inflammation, endothelial dysfunction, and so on. Although evidence of the preventive and therapeutic effects of UA lowering therapy on cardiometabolic diseases is still insufficient, it is expected to be considered as a new treatment strategy for such diseases through additional, carefully designed, large-scale clinical studies.
\end{abstract}

Keywords: Uric acid, Cardiometabolic disease, Cardiovascular disease, Metabolic syndrome

\section{Introduction}

Uric acid (UA) is the end product of purine metabolism in humans, it is formed from xanthine by xanthine oxidase enzyme through several steps and excreted into the urine. UA is endogenously synthesized mainly in the liver, intestines, muscle, and vascular endothelium $[1,2]$. Exogenously, UA can be increased by intake of red meat, seafood, fatty food, alcohol, sugar-sweetened (fructose) drinks, and so on [3-5]. In addition, UA levels are increased in a state of rapid cell turnover such as tumor lysis syndrome, leukemia, lymphoma, or myeloproliferative disease. Hyperuricemia treatment can be divided into two main categories, namely, reducing UA production with xanthine oxidase inhibitors (febuxostat, allopurinol, etc.), and increasing UA excretion by using uricosurics (probenecid, benzbromarone, etc.).

In many mammals, UA is converted to highly soluble allantoin and maintained at very low levels (approximately $1 \mathrm{mg} / \mathrm{dL} ; 60 \mu \mathrm{mol} / \mathrm{L}$ ) [6]. Meanwhile, because the urate oxidase or uricase gene is modified to an

\footnotetext{
* Correspondence: kcmd.sung@samsung.com

†'Seung Jae Lee and Byeong Kil Oh contributed equally to this work.

Division of Cardiology, Department of Internal Medicine, Kangbuk Samsung Hospital, Sungkyunkwan University School of Medicine, 29 Saemunan-ro, Jongno-gu, Seoul 03181, Republic of Korea
}

unexpressed (pseudogene) state in humans, UA is no longer catabolized to allantoin and becomes the end product of purine metabolism. Eventually, UA is maintained at the theoretical limit of solubility in the serum $(6.8 \mathrm{mg} / \mathrm{dL})$, and is periodically excreted in the urine, mostly supersaturated [7].

Pathologically, increased serum UA levels lead to crystal (monosodium urate [MSU]) precipitation in the joints, soft tissue, kidneys, and other organs, which in turn causes various diseases $[8,9]$. It has been known for decades that UA has a significant role in gout and kidney stones formation [7, 10]. Gout, a crystalline arthropathy, has become increasingly common in the last few decades [11]. Its prevalence among US adults is $3.9 \%$, and hyperuricemia prevalence, which is a prerequisite for gout development, is $14.6 \%$ [12]. Furthermore, gout prevalence is $0.76 \%$ in Korea, $1.1 \%$ in China, $2.49 \%$ in the UK, and $0.9 \%$ in France [13-16].

The role of UA in CVD or cardiometabolic disease is still controversial because it is perceived that UA plays a protective role in oxidative stress. Otherwise speaking, UA acts as an active oxygen scavenger in the human body and has an antioxidant effect that prevents cardiovascular diseases $(\mathrm{CVD})$, such as atherosclerosis $[17,18]$.

(c) The Author(s). 2020 Open Access This article is licensed under a Creative Commons Attribution 4.0 International License, which permits use, sharing, adaptation, distribution and reproduction in any medium or format, as long as you give appropriate credit to the original author(s) and the source, provide a link to the Creative Commons licence, and indicate if changes were made. The images or other third party material in this article are included in the article's Creative Commons. licence, unless indicated otherwise in a credit line to the material. If material is not included in the article's Creative Commons licence and your intended use is not permitted by statutory regulation or exceeds the permitted use, you will need to obtain permission directly from the copyright holder. To view a copy of this licence, visit http://creativecommons.org/licenses/by/4.0/. The Creative Commons Public Domain Dedication waiver (http://creativecommons.org/publicdomain/zero/1.0/) applies to the data made available in this article, unless otherwise stated in a credit line to the data. 
In support of this, a study of healthy volunteers showed that the antioxidant effect of UA was substantially greater than that of the ascorbic acid $[19,20]$.

However, several clinical and epidemiological studies have presented the relationship between UA and various disorders including CVD, metabolic syndrome, and kidney disease, thereby overwhelming the beneficial effects of UA [21-25] (Fig. 1). Furthermore, hyperuricemia can be associated with cardiometabolic diseases as an independent risk factor in asymptomatic subjects without comorbidities [26]. In this review, we discuss the relationship between UA and cardiometabolic disease.

\section{Uric acid and hypertension}

Several studies have demonstrated that hyperuricemia is associated with hypertension development [26-28]. A recent meta-analysis study reported that the risk of incident hypertension increased by $13 \%$ for every $1 \mathrm{mg} / \mathrm{dL}$ increase in the UA level [27]. The linear relationship between hypertension and UA levels was valid despite the UA levels being within the normal range, and in the absence of a threshold [29]. We postulated that asymptomatic hyperuricemia in the healthy population demonstrated to be an independent risk factor for the occurrence of incident hypertension [30]. The effect of UA on incident hypertension was more remarkable in younger individuals and women [31]. However, the relationship between UA and hypertension was not related to racial differences [26, 32].
In experimental studies, it was suggested that UA inhibits nitric oxide release from the endothelial cells, activates the renin-angiotensin system, and increases oxidative stress, which damages the endothelial cells and causes vasoconstriction, leading to hypertension development [33-37]. In addition, genetic variations in SLC2A9 and GLUT9, associated with the regulation of UA levels in the human body, are known to be associated with hypertension development [38-41].

\section{Uric acid and coronary heart disease}

CVD is the leading cause of death worldwide, with ischemic heart disease accounting for nearly $50 \%$ of all CVD mortalities, according to the World Health Organization (WHO) estimates [42]. Since the past decades, clinical and experimental studies have suggested that UA was associated with CVD. Furthermore, it was argued that UA could be considered as a potential therapeutic target, proving that it is an independent risk factor for CVD [43, 44]. In an observational cohort study of 5115 recruited young adult participants, hyperuricemia was shown as an independent risk factor for subclinical atherosclerosis [44]. In another large cohort study, the Rotterdam study, 4385 adults aged 55 years and older showed that the increased UA levels were independent prognostic factors of cardiovascular events and all-cause mortality [45]. A meta-analysis study reported that for every $1 \mathrm{mg} / \mathrm{dL}$ increase in the serum UA level, the overall coronary heart disease (CHD) risk

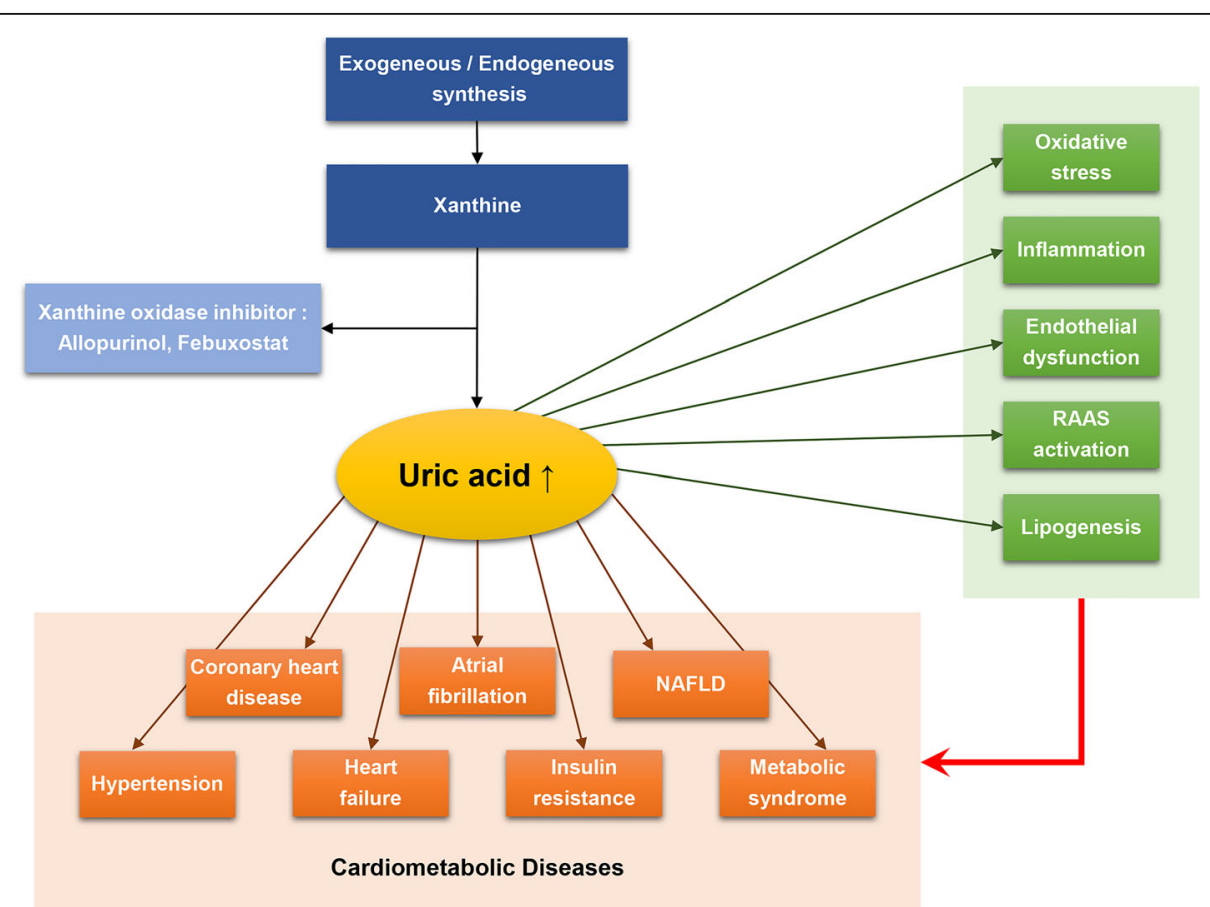

Fig. 1 Schematic diagram showing interplay of uric acid, metabolic syndrome and CVD. CVD, cardiovascular disease; RAS, renin-angiotensinaldosterone system; NAFLD, Non-alcoholic fatty liver disease 
increased by $20 \%$ and all-cause mortality increased by 9\% [46]. In other studies, the UA levels and both allcause and cardiovascular mortalities had a U-shape relationship [47]. Furthermore, the association between UA and CVD was found to be stronger in women than in men [48]. Several cohort and meta-analysis studies of individuals with coronary artery disease have also shown that UA increases mortality [49-51]. A meta-analysis of nine studies with 25,229 patients with confirmed or suspected CHD suggested that every $1 \mathrm{mg} / \mathrm{dL}$ increase in the UA level was associated with a 12 and $20 \%$ increase in the cardiovascular and all-cause mortalities, respectively [51]. Several experimental studies have further suggested that UA causes CHD through the mechanism of reducing nitric oxide in the endothelial cells, inhibiting endothelial proliferation, and inducing platelet adhesiveness as well as activating proliferative and inflammatory pathways in the vascular smooth muscle [52-54]. In addition, it has been hypothesized that UA causes endothelial dysfunction by increasing oxidative stress through xanthine oxidase, thus affecting CHD [55]. Allopurinol, a xanthine oxidase inhibitor, reduced the risk of myocardial infarction (MI); however, colchicine did not support this hypothesis [56].

On the contrary, some studies including ours, have argued that serum UA did not meaningfully improve the prediction of CHD in the general population and was not associated with all-cause and cardiovascular mortalities [57, 58]. Furthermore, two recent Mendelian randomization studies did not demonstrate a clear causal relationship between UA and CHD [59, 60]. Such evidence suggests that further research will need to be carefully conducted, taking into account all possible confounding factors, in order to reach a clear conclusion about the association and causality between UA and CHD.

\section{Uric acid and heart failure}

Hyperuricemia is frequently found in heart failure patients, and UA levels are elevated in more than half of the hospitalized chronic heart failure patients [61, 62]. Hyperuricemia has a deleterious effect on the New York Heart Association (NYHA) class, exercise capacity, oxygen consumption, diastolic dysfunction, and cachexia [63-66]. Several longitudinal studies [67-70] and metaanalyses [71, 72] have assessed the association between $\mathrm{UA}$ and heart failure and found that elevated UA levels not only act as a risk factor for heart failure incidence, but are also associated with the severity of the disease and poor prognosis. Moreover, the Framingham Offspring Cohort Study reported that heart failure incidence rates were about sixfold higher among those at the highest quartile of serum UA $(>6.3 \mathrm{mg} / \mathrm{dL})$ compared to those at the lowest quartile $(<3.4 \mathrm{mg} / \mathrm{dL})$ and the adjusted hazard ratio was 2.1 (95\% CI 1.04-4.22) [73]. A recent meta-analysis demonstrated that for every $1 \mathrm{mg} /$ $\mathrm{dL}$ elevation in serum UA level, the odds of heart failure development increased by $19 \%$ (HR 1.19, 95\% CI 1.171.21 ), and the risk of all-cause mortality increased by $4 \%$ (HR 1.04, 95\% CI 1.02-1.06) [72]. Furthermore, in the British Regional Heart Study, treated hypertensive men with serum UA levels above $410 \mu \mathrm{mol} / \mathrm{L}$ showed an increased risk of heart failure of more than twofold compared to those on treatment with levels below $350 \mu \mathrm{mol} /$ L, even after adjustment for confounding factors [74]. In addition, this study showed that serum UA may be a valuable prognostic marker for heart failure risk in older adults who were treated with hypertension. Although the mechanisms or pathways in which UA affects heart failure development have not yet been clearly identified, it has been postulated to be due to xanthine oxidase upregulation, renin-angiotensin-aldosterone system (RASS) activation, and use of diuretic drugs that may reduce UA excretion [75-78]. Based on these assumptions, serum UA lowering therapy with xanthine oxidase inhibitors such as allopurinol or febuxostat has shown clinical benefits in heart failure patients $[79,80]$. However, some studies have not revealed noteworthy benefits of UA lowering therapy with xanthine oxidase inhibitors in heart failure patients with hyperuricemia; hence, further studies are needed $[81,82]$.

\section{Uric acid and atrial fibrillation}

Recent studies have shown that elevated UA levels are associated with increased risk of atrial fibrillation. A European cohort study involving approximately 6000 patients showed that high baseline UA levels increased the risk of atrial fibrillation [60]. In a study on diabetic patients, the elevated UA levels were associated with the risk of atrial fibrillation [83]. Additionally, recent metaanalysis studies have shown that increased UA levels were associated with an increased risk of atrial fibrillation $[84,85]$. This association was known to be greater in women than in men. The Atherosclerosis Risk in Communities (ARIC) study reported that elevated UA levels increased the risk of atrial fibrillation by 1.16 times, especially in women and blacks [86]. Moreover, our large cohort study has shown that elevated UA levels had a pronounced and independent association with the risk of atrial fibrillation, which was greater in women than in men [87]. Several studies have further suggested a link between sexual differences and UA levels because estradiol plays a role in protecting the endothelial cells and lowering the UA levels $[88,89]$. The mechanism underlying the association between UA and the risk of atrial fibrillation has not been fully elucidated. However, it has been explained that UA causes atrial remodeling by inducing inflammation, oxidative stress, RASS 
activation and endothelial dysfunction, thereby increasing the risk of atrial fibrillation [90-92]. UA causes electrical remodeling, which shortens the atrial refractory period and establishes a reentry circuit in the atrium [91]. Furthermore, UA causes structural remodeling and slows the conduction velocity, thereby allowing reentry [90]. Elevated UA levels increase the nicotinamide adenine dinucleotide phosphate $(\mathrm{NADPH})$ oxidase and xanthine oxidase activity, which in turn increase the reactive oxygen species. Such mechanisms may correspondingly contribute to the pathological consequences of atrial fibrillation such as thrombosis, inflammation, and tissue remodeling [93]. Based on these theories, a number of experimental studies have been published stating that inhibiting xanthine oxidase and NADPH oxidase reduces oxidative stress, and that $\mathrm{N}$ acetylcysteine usage as an antioxidant may be beneficial in atrial fibrillation treatment or prevention. However, further research will be needed to determine the usefulness of these drugs, as research on humans, largely conducted based on highly defined policies, has raised controversial questions due to the disparate outcomes. Most of these studies have been conducted on a limited basis with highly defined populations.

\section{Uric acid and insulin resistance / metabolic syndrome}

Metabolic syndrome (MetS), once called 'Syndrome X' by Raven in the year 1988, is a group of risk factors that increase CVD [94]. From that moment on, there has been some confusion in diagnosis due to the existence of various criteria that define MetS [95-97]. However, several organizations and expert groups, such as the $\mathrm{Na}-$ tional Cholesterol Education Program Adult Treatment Panel III (NCEP:ATPIII), American Association of Clinical Endocrinologists (AACE), International Diabetes Federation (IDF), and American Heart Association/National Heart, Lung, and Blood Institute (AHA/NHLBI), continue to attempt to incorporate different parameters for diagnosing MetS [98]. The NCEP:ATPII defined the components of MetS related to CVD as abdominal obesity, atherogenic dyslipidemia, elevated blood pressure, insulin resistance, and pro-inflammatory and prothrombotic states [99]. Insulin resistance refers to a pathological condition that results in abnormally low insulin sensitivity at the physiological insulin levels, which eventually leads to hyperinsulinemia [100]. Historically, hyperuricemia was frequently observed in MetS, but this was thought to be due to the secondary effect of hyperinsulinemia due to the decreased renal excretion of UA by distal tubular reabsorption [101]. However, a recent epidemiologic study conducted by our group has shown that hyperuricemia often precedes the development of insulin resistance, and that serum UA is an independent risk factor for MetS, including insulin resistance [23]. Additionally, xanthine oxidase inhibitors such as allopurinol not only decreased the UA levels, but also improved insulin resistance and systemic inflammation in asymptomatic individuals with hyperuricemia [102]. The precise mechanism of UA-induced insulin resistance is not yet clear; however, two hypotheses have been suggested. The first hypothesis is that UA inhibits insulin-induced endothelial nitric oxide synthase (eNOS) phosphorylation and subsequent nitric oxide $(\mathrm{NO})$ production, thereby contributing to insulin resistance; therefore, using UA lowering agents such as allopurinol improves insulin resistance [103]. The second hypothesis is that UA affects adipocytes by upregulating the proinflammatory factors and downregulating the insulin sensitizers and anti-inflammatory factors [104]. Experiments using mouse models of MetS have shown that lowering UA by xanthine oxidase inhibitors in obese mice with MetS can improve the inflammatory endocrine imbalance in adipose tissue by increasing the production of adiponectin [104]. Based on these studies, it is necessary to clarify the mechanism by which UA causes insulin resistance in humans and conduct largescale clinical studies to determine the effect of lowering UA levels on insulin resistance.

\section{Uric acid and non-alcoholic fatty liver disease}

Non-alcoholic fatty liver disease (NAFLD) refers to the condition of fat infiltration in the hepatic parenchyma without alcohol abuse, which can potentially lead to liver cirrhosis or liver cancer, and is known to be associated with coexisting conditions such as obesity, type 2 diabetes mellitus, and hyperlipidemia [105]. Recently, a growing number of studies, including our study, have suggested that the elevated serum UA level is associated with an increased risk of NAFLD [24, 106]. The association between serum UA and NAFLD was greater in the obese population as well as in women than in men [107]. In addition, experimental studies using animal models have demonstrated that UA lowering therapy may help in the development and treatment of NAFLD $[108,109]$. The mechanism involved in NAFLD development by UA is not yet clear; however, several hypotheses have been suggested. The first is that increased UA levels increase reactive oxygen species (ROS) production and oxidative stress, leading to pro-inflammatory endocrine imbalance [104]. Second, UA induces lipogenesis by endoplasmic reticulum generation and activation of fatty acid synthase and acetyl-CoA carboxylase, thereby leading to fat accumulation in the hepatocytes [110]. Lastly, UA deteriorates the endothelial function and nitric oxide bioavailability causing insulin resistance, which is the most significant mechanism, resulting in hyperinsulinemia $[108,111]$. 


\section{Conclusions}

As gout prevalence has increased over the past decades, there has been a growing interest in UA, the causative agent of gout. Although there are some controversies due to the ambivalent nature of UA in the human body, several clinical and experimental studies have shown that UA is associated with CVDs and MetS. Moreover, a number of studies have revealed that UA is an independent risk factor for these diseases, suggesting that UA may be a potential therapeutic target for cardiometabolic disease patients, especially those with hyperuricemia, as UA plays a central role. But, there has been some controversy about the causal relationship between hyperuricemia and cardiometabolic disease; uncertainties exist regarding the mechanism of UA-induced cardiometabolic disease. Therefore, it is necessary to elucidate the causal relationship between UA and cardiometabolic disease by further well-controlled, large-scale studies as well as reveal the potential therapeutic and preventive effects of UA lowering therapy in cardiometabolic disease.

\section{Abbreviations}

UA: Uric acid; NAFLD: Non-alcoholic fatty liver disease; CVD: Cardiovascular disease; CHD: Coronary heart disease; MI: Myocardial infarction; RASS: Reninangiotensin-aldosterone system; MetS: Metabolic syndrome

\section{Acknowledgements}

Not applicable.

\section{Authors' contributions}

$\mathrm{SL}$ and $\mathrm{BO}$ contributed to the design and writing of the manuscript. KC coordinated the manuscript, provided references, and is the corresponding author. All authors read and approved the final manuscript.

\section{Funding}

Not applicable.

\section{Availability of data and materials}

Not applicable.

\section{Ethics approval and consent to participate}

Not applicable.

\section{Consent for publication}

Not applicable. No individual data in any form is disclosed.

\section{Competing interests}

The authors declare that they have no competing interests.

Received: 9 February 2020 Accepted: 12 May 2020

Published online: 15 June 2020

\section{References}

1. El Ridi R, Tallima H. Physiological functions and pathogenic potential of uric acid: a review. J Adv Res. 2017:8:487-93.

2. Chaudhary K, Malhotra K, Sowers J, Aroor A. Uric acid - key ingredient in the recipe for cardiorenal metabolic syndrome. Cardiorenal Med. 2013;3:208-20.

3. Choi HK, Atkinson K, Karlson EW, Willett W, Curhan G. Purine-rich foods, dairy and protein intake, and the risk of gout in men. N Engl J Med. 2004; 350:1093-103.

4. Faller J, Fox $\mathbb{H}$. Ethanol-induced hyperuricemia: evidence for increased urate production by activation of adenine nucleotide turnover. N Engl J Med. 1982;307:1598-602.
5. Perez-Pozo SE, Schold J, Nakagawa T, Sanchez-Lozada LG, Johnson RJ, Lillo $J$. Excessive fructose intake induces the features of metabolic syndrome in healthy adult men: role of uric acid in the hypertensive response. Int J Obes. 2010:34:454-61.

6. Johnson RJ, Titte S, Cade JR, Rideout BA, Oliver WJ. Uric acid, evolution and primitive cultures. Semin Nephrol. 2005;25:3-8.

7. Dalbeth N, Merriman TR, Stamp LK. Gout. Lancet. 2016;388:2039-52.

8. Riches PL, Wright AF, Ralston SH. Recent insights into the pathogenesis of hyperuricaemia and gout. Hum Mol Genet. 2009;18:R177-84.

9. Maiuolo J, Oppedisano F, Gratteri S, Muscoli C, Mollace V. Regulation of uric acid metabolism and excretion. Int J Cardiol. 2016;213:8-14.

10. Khan SR, Pearle MS, Robertson WG, Gambaro G, Canales BK, Doizi S, et al. Kidney stones. Nat Rev Dis Primers. 2016;2:16008.

11. Abeles AM. Hyperuricemia, gout, and cardiovascular disease: an update. Curr Rheumatol Rep. 2015;17:13.

12. Singh $G$, Lingala $B$, Mithal $A$. Gout and hyperuricaemia in the USA: prevalence and trends. Rheumatology (Oxford). 2019;58(12):2177-80.

13. Kim JW, Kwak SG, Lee H, Kim SK, Choe JY, Park SH. Prevalence and incidence of gout in Korea: data from the national health claims database 2007-2015. Rheumatol Int. 2017;37:1499-506.

14. Liu R, Han C, Wu D, Xia X, Gu J, Guan H, et al. Prevalence of hyperuricemia and gout in Mainland China from 2000 to 2014: a systematic review and meta-analysis. Biomed Res Int. 2015;2015:762820.

15. Kuo CF, Grainge MJ, Mallen C, Zhang W, Doherty M. Rising burden of gout in the UK but continuing suboptimal management: a nationwide population study. Ann Rheum Dis. 2015;74:661-7.

16. Bardin T, Bouee S, Clerson P, Chales G, Flipo RM, Liote F, et al. Prevalence of gout in the adult population of France. Arthritis Care Res (Hoboken). 2016; 68:261-6.

17. Davies KJ, Sevanian A, Muakkassah-Kelly SF, Hochstein P. Uric acid-iron ion complexes. A new aspect of the antioxidant functions of uric acid. Biochem J. 1986:235:747-54.

18. Nieto FJ, Iribarren C, Gross MD, Comstock GW, Cutler RG. Uric acid and serum antioxidant capacity: a reaction to atherosclerosis? Atherosclerosis. 2000;148:131-9.

19. Waring WS, Webb DJ, Maxwell SR. Systemic uric acid administration increases serum antioxidant capacity in healthy volunteers. J Cardiovasc Pharmacol. 2001;38:365-71.

20. Johnson RJ, Sautin YY, Oliver WJ, Roncal C, Mu W, Gabriela Sanchez-Lozada $L$, et al. Lessons from comparative physiology: could uric acid represent a physiologic alarm signal gone awry in western society? J Comp Physiol B. 2009:179:67-76.

21. Borghi C, Rodriguez-Artalejo F, De Backer G, Dallongeville J, Medina J, Nuevo J, et al. Serum uric acid levels are associated with cardiovascular risk score: a post hoc analysis of the EURIKA study. Int J Cardiol. 2018;253:167-73.

22. Fang J, Alderman MH. Serum uric acid and cardiovascular mortality the NHANES I epidemiologic follow-up study, 1971-1992. National Health and Nutrition Examination Survey. JAMA. 2000;283:2404-10.

23. Yoo TW, Sung KC, Shin HS, Kim BJ, Kim BS, Kang JH, et al. Relationship between serum uric acid concentration and insulin resistance and metabolic syndrome. Circ J. 2005;69:928-33.

24. Lee JW, Cho YK, Ryan M, Kim H, Lee SW, Chang E, et al. Serum uric acid as a predictor for the development of nonalcoholic fatty liver disease in apparently healthy subjects: a 5-year retrospective cohort study. Gut Liver. 2010:4:378-83.

25. Chonchol M, Shlipak MG, Katz R, Sarnak MJ, Newman AB, Siscovick DS, et al. Relationship of uric acid with progression of kidney disease. Am J Kidney Dis. 2007:50:239-47

26. Kuwabara M, Niwa K, Hisatome I, Nakagawa T, Roncal-Jimenez CA, AndresHernando A, et al. Asymptomatic hyperuricemia without comorbidities predicts cardiometabolic diseases: five-year Japanese cohort study. Hypertension. 2017;69:1036-44.

27. Wang J, Qin T, Chen J, Li Y, Wang L, Huang H, et al. Hyperuricemia and risk of incident hypertension: a systematic review and meta-analysis of observational studies. PLoS One. 2014;9:e114259.

28. Buzas R, Tautu OF, Dorobantu M, Ivan V, Lighezan D. Serum uric acid and arterial hypertension-data from Sephar III survey. PLoS One. 2018;13: e0199865.

29. Leiba A, Vinker S, Dinour D, Holtzman EJ, Shani M. Uric acid levels within the normal range predict increased risk of hypertension: a cohort study. J Am Soc Hypertens. 2015;9:600-9. 
30. Sung KC, Byrne CD, Ryu S, Lee JY, Lee SH, Kim JY, et al. Baseline and change in uric acid concentration over time are associated with incident hypertension in large Korean cohort. Am J Hypertens. 2017;30:42-50.

31. Lee JJ, Ahn J, Hwang J, Han SW, Lee KN, Kim JB, et al. Relationship between uric acid and blood pressure in different age groups. Clin Hypertens. 2015;21:14.

32. Longo-Mbenza B, Luila EL, Mbete P, Vita EK. Is hyperuricemia a risk factor of stroke and coronary heart disease among Africans? Int J Cardiol. 1999:71:17-22.

33. De Becker B, Borghi C, Burnier M, van de Borne P. Uric acid and hypertension: a focused review and practical recommendations. J Hypertens. 2019:37:878-83.

34. Khosla UM, Zharikov S, Finch JL, Nakagawa T, Roncal C, Mu W, et al. Hyperuricemia induces endothelial dysfunction. Kidney Int. 2005;67:1739-42.

35. Chao HH, Liu JC, Lin JW, Chen $\mathrm{CH}, \mathrm{Wu} \mathrm{CH}$, Cheng TH. Uric acid stimulates endothelin-1 gene expression associated with NADPH oxidase in human aortic smooth muscle cells. Acta Pharmacol Sin. 2008;29:1301-12.

36. Yu MA, Sanchez-Lozada LG, Johnson RJ, Kang DH. Oxidative stress with an activation of the renin-angiotensin system in human vascular endothelial cells as a novel mechanism of uric acid-induced endothelial dysfunction. J Hypertens. 2010;28:1234-42.

37. Corry DB, Eslami P, Yamamoto K, Nyby MD, Makino H, Tuck ML. Uric acid stimulates vascular smooth muscle cell proliferation and oxidative stress via the vascular renin-angiotensin system. J Hypertens. 2008;26:269-75.

38. DeBosch BJ, Kluth O, Fujiwara H, Schurmann A, Moley K. Early-onset metabolic syndrome in mice lacking the intestinal uric acid transporter SLC2A9. Nat Commun. 2014;5:4642.

39. Neogi T. Clinical practice. Gout. N Engl J Med. 2011;364:443-52.

40. Parsa A, Brown E, Weir MR, Fink JC, Shuldiner AR, Mitchell BD, et al. Genotype-based changes in serum uric acid affect blood pressure. Kidney Int. 2012;81:502-7.

41. Mallamaci F, Testa A, Leonardis D, Tripepi R, Pisano A, Spoto B, et al. A polymorphism in the major gene regulating serum uric acid associates with clinic SBP and the white-coat effect in a family-based study. J Hypertens. 2014;32:1621-8 discussion 8.

42. Nowbar AN, Gitto M, Howard JP, Francis DP, Al-Lamee R. Mortality from ischemic heart disease. Circ Cardiovasc Qual Outcomes. 2019;12:e05375.

43. Okura T, Higaki J, Kurata M, Irita J, Miyoshi K, Yamazaki T, et al. Elevated serum uric acid is an independent predictor for cardiovascular events in patients with severe coronary artery stenosis: subanalysis of the Japanese Coronary Artery Disease (JCAD) study. Circ J. 2009;73:885-91.

44. Krishnan E, Pandya BJ, Chung L, Dabbous O. Hyperuricemia and the risk for subclinical coronary atherosclerosis--data from a prospective observational cohort study. Arthritis Res Ther. 2011;13:R66.

45. Bos MJ, Koudstaal PJ, Hofman A, Witteman JC, Breteler MM. Uric acid is a risk factor for myocardial infarction and stroke: the Rotterdam study. Stroke. 2006:37:1503-7.

46. Zuo T, Liu X, Jiang L, Mao S, Yin X, Guo L. Hyperuricemia and coronary heart disease mortality: a meta-analysis of prospective cohort studies. BMC Cardiovasc Disord. 2016;16:207.

47. Kuo CF, See LC, Yu KH, Chou IJ, Chiou MJ, Luo SF. Significance of serum uric acid levels on the risk of all-cause and cardiovascular mortality. Rheumatology (Oxford). 2013;52:127-34

48. Kim SY, Guevara JP, Kim KM, Choi HK, Heitjan DF, Albert DA. Hyperuricemia and coronary heart disease: a systematic review and meta-analysis. Arthritis Care Res (Hoboken). 2010;62:170-80.

49. Ioachimescu AG, Brennan DM, Hoar BM, Hazen SL, Hoogwerf BJ. Serum uric acid is an independent predictor of all-cause mortality in patients at high risk of cardiovascular disease: a preventive cardiology information system (PreCIS) database cohort study. Arthritis Rheum. 2008:58:623-30.

50. Ndrepepa G, Braun S, King L, Hadamitzky M, Haase HU, Birkmeier KA, et al. Association of uric acid with mortality in patients with stable coronary artery disease. Metabolism. 2012;61:1780-6.

51. Wang $R$, Song $Y$, Yan $Y$, Ding Z. Elevated serum uric acid and risk of cardiovascular or all-cause mortality in people with suspected or definite coronary artery disease: a meta-analysis. Atherosclerosis. 2016;254:193-9.

52. Kang DH, Park SK, Lee IK, Johnson RJ. Uric acid-induced C-reactive protein expression: implication on cell proliferation and nitric oxide production of human vascular cells. J Am Soc Nephrol. 2005;16:3553-62.

53. Kanellis J, Watanabe S, Li JH, Kang DH, Li P, Nakagawa T, et al. Uric acid stimulates monocyte chemoattractant protein-1 production in vascular smooth muscle cells via mitogen-activated protein kinase and cyclooxygenase-2. Hypertension. 2003;41:1287-93.

54. Fuster V, Badimon L, Badimon JJ, Chesebro JH. The pathogenesis of coronary artery disease and the acute coronary syndromes (1). N Engl J Med. 1992;326:242-50.

55. George J, Struthers AD. The role of urate and xanthine oxidase inhibitors in cardiovascular disease. Cardiovasc Ther. 2008;26:59-64.

56. Grimaldi-Bensouda L, Alperovitch A, Aubrun E, Danchin N, Rossignol M, Abenhaim $L$, et al. Impact of allopurinol on risk of myocardial infarction. Ann Rheum Dis. 2015;74:836-42.

57. Wheeler JG, Juzwishin KD, Eiriksdottir G, Gudnason V, Danesh J. Serum uric acid and coronary heart disease in 9,458 incident cases and 155,084 controls: prospective study and meta-analysis. PLoS Med. 2005; 2:e76

58. Cheong E, Ryu S, Lee JY, Lee SH, Sung JW, Cho DS, et al. Association between serum uric acid and cardiovascular mortality and all-cause mortality: a cohort study. J Hypertens. 2017:35(Suppl 1):S3-9.

59. Li X, Meng X, Timofeeva M, Tzoulaki I, Tsilidis KK, loannidis JP, et al. Serum uric acid levels and multiple health outcomes: umbrella review of evidence from observational studies, randomised controlled trials, and Mendelian randomisation studies. BMJ. 2017;357:j2376.

60. Keenan T, Zhao W, Rasheed A, Ho WK, Malik R, Felix JF, et al. Causal assessment of serum urate levels in cardiometabolic diseases through a Mendelian randomization study. J Am Coll Cardiol. 2016;67:407-16.

61. Hamaguchi S, Furumoto T, Tsuchihashi-Makaya M, Goto K, Goto D, Yokota T, et al. Hyperuricemia predicts adverse outcomes in patients with heart failure. Int J Cardiol. 2011;151:143-7.

62. Thanassoulis G, Brophy JM, Richard H, Pilote L. Gout, allopurinol use, and heart failure outcomes. Arch Intern Med. 2010;170:1358-64

63. Doehner W, Rauchhaus M, Florea VG, Sharma R, Bolger AP, Davos CH, et al. Uric acid in cachectic and noncachectic patients with chronic heart failure: relationship to leg vascular resistance. Am Heart J. 2001;141:792-9.

64. Leyva F, Anker S, Swan JW, Godsland IF, Wingrove CS, Chua TP, et al. Serum uric acid as an index of impaired oxidative metabolism in chronic heart failure. Eur Heart J. 1997;18:858-65.

65. Amin A, Vakilian F, Maleki M. Serum uric acid levels correlate with filling pressures in systolic heart failure. Congest Heart Fail. 2011;17:80-4.

66. Cicoira M, Zanolla L, Rossi A, Golia G, Franceschini L, Brighetti G, et al. Elevated serum uric acid levels are associated with diastolic dysfunction in patients with dilated cardiomyopathy. Am Heart J. 2002;143:1107-11.

67. Anker SD, Doehner W, Rauchhaus M, Sharma R, Francis D, Knosalla C, et al. Uric acid and survival in chronic heart failure: validation and application in metabolic, functional, and hemodynamic staging. Circulation. 2003;107: 1991-7.

68. Ekundayo OJ, Dell'Italia LJ, Sanders PW, Arnett D, Aban I, Love TE, et al. Association between hyperuricemia and incident heart failure among older adults: a propensity-matched study. Int J Cardiol. 2010;142:279-87.

69. Holme I, Aastveit AH, Hammar N, Jungner I, Walldius G. Uric acid and risk of myocardial infarction, stroke and congestive heart failure in 417,734 men and women in the Apolipoprotein MOrtality RISk study (AMORIS). J Intern Med. 2009;266:558-70

70. Wu AH, Ghali JK, Neuberg GW, O'Connor CM, Carson PE, Levy WC. Uric acid level and allopurinol use as risk markers of mortality and morbidity in systolic heart failure. Am Heart J. 2010;160:928-33.

71. Tamariz L, Harzand A, Palacio A, Verma S, Jones J, Hare J. Uric acid as a predictor of all-cause mortality in heart failure: a meta-analysis. Congest Heart Fail. 2011;17:25-30.

72. Huang H, Huang B, Li Y, Huang Y, Li J, Yao H, et al. Uric acid and risk of heart failure: a systematic review and meta-analysis. Eur J Heart Fail. 2014;16: $15-24$.

73. Krishnan E. Hyperuricemia and incident heart failure. Circ Heart Fail. 2009;2: 556-62.

74. Wannamethee SG, Papacosta O, Lennon L, Whincup PH. Serum uric acid as a potential marker for heart failure risk in men on antihypertensive treatment: the British regional heart study. Int J Cardiol. 2018;252:187-92.

75. Kanbay M, Segal M, Afsar B, Kang DH, Rodriguez-Iturbe B, Johnson RJ. The role of uric acid in the pathogenesis of human cardiovascular disease. Heart. 2013:99:759-66.

76. Hare JM, Johnson RJ. Uric acid predicts clinical outcomes in heart failure: insights regarding the role of xanthine oxidase and uric acid in disease pathophysiology. Circulation. 2003;107:1951-3. 
77. Berry CE, Hare JM. Xanthine oxidoreductase and cardiovascular disease: molecular mechanisms and pathophysiological implications. J Physiol. 2004; 555:589-606.

78. Reyes AJ. The increase in serum uric acid concentration caused by diuretics might be beneficial in heart failure. Eur J Heart Fail. 2005;7:461-7.

79. Doehner W, Schoene N, Rauchhaus M, Leyva-Leon F, Pavitt DV, Reaveley DA, et al. Effects of xanthine oxidase inhibition with allopurinol on endothelial function and peripheral blood flow in hyperuricemic patients with chronic heart failure: results from 2 placebo-controlled studies. Circulation. 2002:105:2619-24.

80. Xu X, Hu X, Lu Z, Zhang P, Zhao L, Wessale JL, et al. Xanthine oxidase inhibition with febuxostat attenuates systolic overload-induced left ventricular hypertrophy and dysfunction in mice. J Card Fail. 2008;14:746-53.

81. Givertz MM, Anstrom KJ, Redfield MM, Deswal A, Haddad H, Butler J, et al. Effects of xanthine oxidase inhibition in hyperuricemic heart failure patients: the xanthine oxidase inhibition for hyperuricemic heart failure patients (EXACT-HF) study. Circulation. 2015:131:1763-71.

82. Hare JM, Mangal B, Brown J, Fisher C Jr, Freudenberger R, Colucci WS, et al. Impact of oxypurinol in patients with symptomatic heart failure. Results of the OPT-CHF study. J Am Coll Cardiol. 2008;51:2301-9.

83. Valbusa F, Bertolini L, Bonapace S, Zenari L, Zoppini G, Arcaro G, et al. Relation of elevated serum uric acid levels to incidence of atrial fibrillation in patients with type 2 diabetes mellitus. Am J Cardiol. 2013;112:499-504.

84. Tamariz L, Hernandez F, Bush A, Palacio A, Hare JM. Association between serum uric acid and atrial fibrillation: a systematic review and meta-analysis. Heart Rhythm. 2014;11:1102-8

85. Zhang $\mathrm{CH}$, Huang DS, Shen D, Zhang LW, Ma YJ, Wang YM, et al. Association between serum uric acid levels and atrial fibrillation risk. Cell Physiol Biochem. 2016:38:1589-95.

86. Tamariz L, Agarwal S, Soliman EZ, Chamberlain AM, Prineas R, Folsom AR, et al. Association of serum uric acid with incident atrial fibrillation (from the Atherosclerosis Risk in Communities [ARIC] study). Am J Cardiol. 2011;108: 1272-6

87. Kwon CH, Lee SH, Lee JY, Ryu S, Sung KC. Uric acid and risk of atrial fibrillation in the Korean general population. Circ J. 2018;82:2728-35.

88. Prasad M, Matteson EL, Herrmann J, Gulati R, Rihal CS, Lerman LO, et al. Uric acid is associated with inflammation, coronary microvascular dysfunction, and adverse outcomes in postmenopausal women. Hypertension. 2017;69: 236-42

89. Hak AE, Choi HK. Menopause, postmenopausal hormone use and serum uric acid levels in US women--the third national health and nutrition examination survey. Arthritis Res Ther. 2008;10:R116.

90. Maharani N, Kuwabara M, Hisatome I. Hyperuricemia and atrial fibrillation. Int Heart J. 2016:57:395-9.

91. Iwasaki YK, Nishida K, Kato T, Nattel S. Atrial fibrillation pathophysiology: implications for management. Circulation. 2011;124:2264-74.

92. Hu YF, Chen YJ, Lin YJ, Chen SA. Inflammation and the pathogenesis of atrial fibrillation. Nat Rev Cardiol. 2015;12:230-43.

93. Dudley SC Jr, Hoch NE, McCann LA, Honeycutt C, Diamandopoulos L, Fukai $T$, et al. Atrial fibrillation increases production of superoxide by the left atrium and left atrial appendage: role of the NADPH and xanthine oxidases. Circulation. 2005;112:1266-73.

94. Reaven GM. Banting lecture 1988. Role of insulin resistance in human disease. Diabetes. 1988;37:1595-607.

95. Expert Panel on Detection E, Treatment of High Blood Cholesterol in A. Executive summary of the third report of the National Cholesterol Education Program (NCEP) expert panel on detection, evaluation, and treatment of high blood cholesterol in adults (Adult Treatment Panel III). JAMA. 2001:285:2486-97.

96. Einhorn D, Reaven GM, Cobin RH, Ford E, Ganda OP, Handelsman Y, et al. American College of Endocrinology position statement on the insulin resistance syndrome. Endocr Pract. 2003;9:237-52.

97. Alberti KG, Zimmet P, Shaw J, Group IDFETFC. The metabolic syndrome--a new worldwide definition. Lancet. 2005:366:1059-62.

98. Alberti KG, Eckel RH, Grundy SM, Zimmet PZ, Cleeman Jl, Donato KA, et al. Harmonizing the metabolic syndrome: a joint interim statement of the International Diabetes Federation Task Force on Epidemiology and Prevention; National Heart, Lung, and Blood Institute; American Heart Association; World Heart Federation; International Atherosclerosis Society; and International Association for the Study of Obesity. Circulation. 2009;120:1640-5.
99. National Cholesterol Education Program Expert Panel on Detection E, Treatment of High Blood Cholesterol in A. Third report of the National Cholesterol Education Program (NCEP) expert panel on detection, evaluation, and treatment of high blood cholesterol in adults (Adult Treatment Panel III) final report. Circulation. 2002;106:3143-421.

100. Wang G. Raison d'etre of insulin resistance: the adjustable threshold hypothesis. J R Soc Interface. 2014;11:20140892.

101. Facchini F, Chen YD, Hollenbeck CB, Reaven GM. Relationship between resistance to insulin-mediated glucose uptake, urinary uric acid clearance, and plasma uric acid concentration. JAMA. 1991;266:3008-11.

102. Takir M, Kostek O, Ozkok A, Elcioglu OC, Bakan A, Erek A, et al. Lowering uric acid with allopurinol improves insulin resistance and systemic inflammation in asymptomatic hyperuricemia. J Investig Med. 2015;63:924-9.

103. Choi YJ, Yoon Y, Lee KY, Hien T, Kang KW, Kim KC, et al. Uric acid induces endothelial dysfunction by vascular insulin resistance associated with the impairment of nitric oxide synthesis. FASEB J. 2014;28:3197-204.

104. Baldwin W, McRae S, Marek G, Wymer D, Pannu V, Baylis C, et al. Hyperuricemia as a mediator of the proinflammatory endocrine imbalance in the adipose tissue in a murine model of the metabolic syndrome. Diabetes. 2011;60:1258-69.

105. Angulo P. Nonalcoholic fatty liver disease. N Engl J Med. 2002;346:1221-31.

106. Jensen T, Niwa K, Hisatome I, Kanbay M, Andres-Hernando A, RoncalJimenez CA, et al. Increased serum uric acid over five years is a risk factor for developing fatty liver. Sci Rep. 2018;8:11735.

107. Zhou Y, Wei F, Fan Y. High serum uric acid and risk of nonalcoholic fatty liver disease: a systematic review and meta-analysis. Clin Biochem. 2016:49: 636-42.

108. Wan X, Xu C, Lin Y, Lu C, Li D, Sang J, et al. Uric acid regulates hepatic steatosis and insulin resistance through the NLRP3 inflammasomedependent mechanism. J Hepatol. 2016;64:925-32.

109. Xu C, Wan X, Xu L, Weng H, Yan M, Miao M, et al. Xanthine oxidase in nonalcoholic fatty liver disease and hyperuricemia: one stone hits two birds. J Hepatol. 2015;62:1412-9.

110. Choi YJ, Shin HS, Choi HS, Park JW, Jo I, Oh ES, et al. Uric acid induces fat accumulation via generation of endoplasmic reticulum stress and SREBP-1C activation in hepatocytes. Lab Investig. 2014;94:1114-25.

111. Zhu Y, Hu Y, Huang T, Zhang Y, Li Z, Luo C, et al. High uric acid directly inhibits insulin signalling and induces insulin resistance. Biochem Biophys Res Commun. 2014:447:707-14.

\section{Publisher's Note}

Springer Nature remains neutral with regard to jurisdictional claims in published maps and institutional affiliations.

Ready to submit your research? Choose BMC and benefit from:

- fast, convenient online submission

- thorough peer review by experienced researchers in your field

- rapid publication on acceptance

- support for research data, including large and complex data types

- gold Open Access which fosters wider collaboration and increased citations

- maximum visibility for your research: over $100 \mathrm{M}$ website views per year

At $\mathrm{BMC}$, research is always in progress.

Learn more biomedcentral.com/submission 